\title{
Land Policies, Land-based Development Programs and the Question of Minority Rights in Eastern Sri Lanka
}

\author{
Mohammad Agus Yusoff ${ }^{1}$, Athambawa Sarjoon ${ }^{1,2}$, Azmi Awang ${ }^{3}$ \& Izham Hakim Hamdi $^{4}$ \\ ${ }^{1}$ School of History, Politics and Strategic Studies, Faculty of Social Sciences and Humanities, Universiti \\ Kabangsaan Malaysia, UKM Bangi 43600, Selangor, Malaysia \\ ${ }^{2}$ Department of Political Science, University of Peradeniya, Peradeniya, Sri Lanka \\ ${ }^{3}$ Road Transport Department Malaysia, Malaysia \\ ${ }^{4} \mathrm{PhD}$ Student, Universiti Putra Malaysia, Malaysia \\ Correspondence: Mohammad Agus Yusoff, School of History, Politics and Strategic Studies, Faculty of Social \\ Sciences and Humanities, Universiti Kabangsaan Malaysia, UKM Bangi 43600, Selangor, Malaysia. Email: \\ agus_@ukm.my
}

Received: July 2, 2015 Accepted: August 3, 2015 Online Published: September 27, 2015

doi:10.5539/jsd.v8n8p223 URL: http://dx.doi.org/10.5539/jsd.v8n8p223

\begin{abstract}
Land has been one of the major concerning factors in escalating disputes and conflicts between ethnic groups in Sri Lanka, including the violation of minority rights. This paper examines the impact of land policies and land-based development programs on the rights of ethnic minorities in eastern Sri Lanka by analyzing selected major policies and projects. The analysis is interpretive and descriptive in nature. Secondary literature was the primary source for the analysis. The results found that the majority of land policies and programs were designed and implemented in favor of the ethnic majority - the Sinhalese - and violated the land-based rights of ethnic minorities, thereby leading to many problems and challenges. Findings further revealed that not only were these policies and projects intended to reduce the ethnic balance of the minorities in the region, but they also resulted in territorial political claims among the ethnic minorities in the region.
\end{abstract}

Keywords: land policies, land settlement programs, minority rights, Eastern Sri Lanka

\section{Introduction}

The human's wellbeing, progress, and peaceful life are related to the soil, sunshine, river system, forest, and natural resources of their native land. However, land is a highly politicized and ethnicized issue that has been widely perceived as being central to the breaking up of ethnic relations and intensified ethno-political conflict in Sri Lanka since independence. This includes not only land policies, but also a number of state-sponsored land distribution (colonization) schemes that were implemented in the 1950s, 1960s, and 1970s, which attempted to move the Sinhalese into Tamil and Muslim dominant areas in the north-eastern region. This negatively impacted the traditional territory of Tamil-speakers and became a driving force in aggravating tensions and conflict between the ethnic-majorities and ethnic-minorities in the region. Over the course of time, land has become one of the major root causes of ethnic conflict and ethnic politics in Sri Lanka. The continuous population transfer into lands in the north-eastern region predominated by Tamil-speakers through a number of state-aided policies and projects has compelled the Tamils and Muslims to intensify their advocacy for territorial-based political claims and bargaining in national politics. Based on this backdrop, this paper attempts to examine the impact of land policies and land-based settlement projects implemented by successive governments on the socio-economic and political life of Tamil-speaking minorities, especially those living in eastern Sri Lanka. The main objective of this study is to review the main features of these land policies and land-based settlement projects of successive governments, and examine their impact on the rights and interests of ethnic minorities in the eastern province of Sri Lanka. The analysis adopted in this paper is interpretive and descriptive in nature and secondary data was mainly used for the establishment of arguments for and against. The analysis was conducted through critically reviewing a number of land policies and land settlement projects and their impact.

\section{Nature of Land Policies and Land Settlement Programs in Sri Lanka: A historical Note}

The land policies of the successive Sri Lankan governments have resulted in minority ethnic groups in Sri Lanka 
having to face a number of issues. Land policies in Sri Lanka are governed by several factors. Both colonization and land settlement schemes planned through these land policies gained momentum and took a dramatic turn after independence. Rupasinge (2002:14-15) has identified the objectives and characteristics of land policies in Sri Lanka as follows:

a) The need to satisfy the land hunger of the Sinhalese peasantry,

b) A policy to stop the forward expansion of the Tamil and Muslim population,

c) A policy to change the demographic pattern of the Eastern province through delimitation of boundaries and the carving out of electoral divisions favorable to the Sinhalese, (and later)

d) The pursuit of geo-military security interests where Sinhalese settlements were encouraged to create a security zone in such places as Weli Oya (in Trincomalee).

Historically, in Sri Lanka, land ownership dramatically underwent changes during the British colonial period (1796-1948). During this period, the colonial rulers granted land to those who served well in their administration. Through this system of colonial patronage, land was bestowed on minorities, especially the Tamils and the Muslims who were trusted by the colonial rulers and had therefore gained good name amongst the rulers. This policy led to large land holdings being distributed amongst the clients of the colonial system. However, after independence, through the 'Grow More Food' campaigns of the Sri Lankan government 'grown lands' were allotted mainly to Sinhalese, but as Rupasinghe (2002) indicates, Tamils and Muslims have also benefited. On this basis, a number of irrigation-based land settlement projects were initiated by successive post-independence governments, in order to provide land and livelihood opportunities for landless people across the country. However, these settlements later resulted in land being viewed as a root cause of conflict between ethnic groups, leading to civil war. Through these projects, on one hand, minorities living in the north-eastern region began to lose their lands due to the state seizure of their lands; on the other hand, the demographic set-up in the region became changed over the course of time. Subsequently, these projects ultimately threatened ethnic relations and caused the emergence of territorial-based political demands, eventually leading to violent ethnic conflict in Sri Lanka on a great scale.

Land settlement and colonization in the dry zone began in the earliest part of the twentieth century during the colonial period. Colonization in administrative terms derived from the British can be defined as to settle down local people in a new area of agriculture. Government expenditure on irrigation had dwindled by 1905, but the revitalization of the dry zone then became a matter of particular urgency for Sinhalese nationalist politicians. This revitalization was particularly important to the Low-Country Sinhalese elites, for whom it was a means of appealing to the Kandyan Sinhalese, the people identified as suffering most from landlessness. Therefore, when a land commission in 1927 declared that the government must hold 'Grown land' in trust for all people and allocate it for their benefit, the State Council under Don Stephen Senanayake's leadership planned colonization schemes in the dry zone encouraging landless Sinhalese peasants to become independent peasant proprietors. The Land Development Ordinance of 1935 created further mechanisms for this colonization. The stated objectives of this colonization were to relieve unemployment in the wet zone, to increase food production, and to establish prosperous settlement in the dry zone (Peebles, 1990:37). Later on, this ordinance became the basis or source of all land-based development and settlement projects implemented in the country. Using this and successive policies, the Sri Lankan post-independent governments implemented a number of land-based development and colonization projects with a number of objectives. One of the regions that received more attention from the rulers, policy-makers, and nationalists in terms of land-based settlement and development was the eastern province. These government projects have impacted the entire life of ethnic minorities in this region in many ways. The following section extensively reviews the major projects and their influence on minorities.

\section{Land-colonization in the Eastern Region of Sri Lanka}

The land policies and land-based settlement programs initially targeted the eastern region of the country. The northern and eastern regions of Sri Lanka have traditionally been Tamil-speaker (Tamils and Muslims) predominated regions. Ethnically too, this group differs from the majority group of the country, the Sinhalese. Since there had been independent Tamil-kingdoms in the north-eastern region, Tamils had identified the region as the 'traditional homeland' of Tamil-speakers. The homeland concept was an influential one in ethnic politics even before independence in Sri Lanka. Tamil politicians were claiming and advocating territorial autonomy in the north-eastern region even before independence. However, this idea received huge criticism from the majority Sinhalese. Therefore, when political power was transferred to them from the colonial rulers, their concern mainly focused on undermining the territorial autonomy discourse of the Tamils. They used land policies and land settlement programs in order to sabotage these autonomy discourses and advocacies. 
The British colonial government inaugurated the development of the irrigation tanks in the eastern districts in 1881. However, these developments only facilitated the agriculture of the local population and did not create any demographic changes in the region. Conversely, the land settlement programs and irrigation-based development projects implemented by the post-independent governments through land policies were targeted not only at seizing the lands owned by Tamil-speakers, but also at settling more Sinhalese in the region. Consequently, soon after independence from the British colonial powers in 1948, the Sinhala population in the eastern province tripled in size while the size of the Tamil and the Muslim population reduced or remained roughly the same.

Post-independence government-sponsored colonization schemes intended to settle more Sinhalese in eastern provinces in conjunction with the construction of irrigation-based development projects can be traced back to as early as the late 1940s. The schemes commenced with the Kanthalai colonization scheme in the south-eastern part of the Trincomalee district in 1948, during the Premiership of D.S Senanayake, the father of the nation. This was followed by the Gal Oya settlement scheme in the south-west of the Batticaloa district in 1949, the Allai scheme in 1953, and the Padaviya colonization scheme in 1958. This continued in 1960s with the construction of Morawewa scheme, followed by the Weli Oya settlements - later re-christened as the Mahaweli ' $\mathrm{L}$ ' scheme in 1983. Under the auspices of the above various irrigation-based land settlement and development schemes, Sinhalese peasants were encouraged from the 1950s through the 1980s to move into many parts of the eastern province by providing them with irrigable agricultural lands and basic amenities. According to International Crisis Group [ICG] (2012:23), by the late 1960s, the government had alienated more than 300,000 acres of land to 67,000 allotters in these major colonization schemes. The settlement of so many Sinhalese in the districts of the eastern province which were, at independence, almost entirely Tamil-speaking, was politically explosive and emerged as one of the major grievances expressed by the Tamil and Muslim public, their political leaders, and the Tamil militant groups, including the major militant group fighting for the liberation of Tamils in north-eastern Sri Lanka - the Liberation Tigers of Tamil Eealam (LTTE).

\subsection{Kanthalai, Allai and Moraweva Schemes in the Trincomalee District and Their Impact}

The land settlement and development policies and projects of successive post-independent governments in Sri Lanka have been a major factor in altering the demography of the eastern province in favor of the Sinhalese. The so-called land settlement and colonization schemes were boosted by the political elites of the central government in order to settle more Sinhalese in eastern Sri Lanka as a strategic way to weaken the ethnic balance of minorities and sabotage their territorial-based autonomy claims. An analysis of the historical background of these projects and their impact clearly justifies this argument. Colonization schemes in the eastern province started in Kanthalai in the Trincomalee district, followed by Allai and Moraweva in the same district. There is a tank in Kanthalai (also named as Gangathala Vapi which was built by King Aggrabodhi the II (606-618) and rehabilitated and developed by King Parakramabahu the Great) that originally was used to irrigate the paddy fields belonging to the Thamplakamam and Kinniya farmers, who were mostly the Tamil-speaking Muslims and Tamils. The government started a land settlement project in 1948 intended to settle more landless people targeting the water tank. The magnitude of impact of this colonization project can be seen from the fact that in the early 1900's, the entire present Kanthalai Divisional Secretariat (DS) division formed the only one Village Headman's (presently the Grama Niladari (GN) officer's) division, in the then Thampalakamam Divisional Revenue Officer's (DRO) division (later Assistant Government Agent (AGA) division) (Note 1). However, after the establishment of the Kanthalai colonization project, in order to facilitate the colonization scheme, the one and only GN officer's division was made into an AGA division with $23 \mathrm{GN}$ officer's divisions. In the beginning of the 1990s, the UTHR(J) (1993) estimated that about 40,000 of the 86,000 Sinhalese population in the district migrated there as a result of the Kanthalai colonization scheme.

The Allai colonization scheme began by constructing an anicut across the Verugal river, a tributary of the Mahaweli Ganga. The entire region receiving irrigation water from this scheme was called the Koddiyar AGA's division at that time. Koddiyar was also called Koddiyarpuram in Tamil. Tamils and Muslims had lived in this area peacefully from ancient times. There are now three DS divisions located here. One is presently called the Muthur DS division. The second is called the Seruvila DS division, and the third is the Verugal DS division, located at Ichchilampattai. Several new Sinhalese villages have sprung up, swallowing many ancient Tamil villages consequent to the Allai irrigation scheme. The DS division of Seruvila is located at Serunuvara, which was originally called Arippu. It has been identified that $99 \%$ of the Sinhalese living in this division are outsiders colonized by the government through this Allai colonization scheme (See: UTHR(J) 1993).

Mowawewa is another irrigation based colonization scheme that was started in 1961 in the Trincomalee district. Morawewa is the Sinhalese translation of the Tamil word Mudalikulam (Mudali tank), and is located 24 kilometres west of the Trincomalee town. This tank became the centre of a colonisation scheme in the 1960s and 
included Tamils also as beneficiaries. A new AGA's division was created in 1976 for Morawewa, bypassing the priority list originally sent by the Government Agent (GA), Trincomalee. According to the 2012 census, the Morawewa DS division has a population of 7,968 in its $10 \mathrm{GN}$ officer divisions. The Sinhalese constitute $72.3 \%$ of the division's total population, and a considerable percentage of them are outsiders settled through this project.

The major impact of the above land settlement and colonization programs was the demographic change of the district, especially the reduction of minority populations. As noted earlier, these programs' objective was to settle more Sinhalese in the region through providing state lands with necessary amenities. It is worth noting here that the Sinhalese population of $4.40 \%$ in the Trincomalee district in 1921 is increased to $26.97 \%$ in 2012 . Table- 1 clearly illustrates how the district's population in terms of ethnic groups has changed within this 90 -years period. The ethnic group most affected in this district by these land-based colonization projects is the Tamils, who initially held a majority with $54.47 \%$ of the district's population in 1921 , but now has lost nearly $22 \%$ of their population strength. Over the course of time, in order to politically and administratively facilitate these settlements, a new constituency called Seruwela was formed during the 1970s dividing the Tamil-Muslim-majority Muttur constituency, and more new AGA divisions were also created for a small number of Sinhalese families (mostly the settlers) with the waste allocation of land.

Table 1. The changing ethnic balance in population of Trincomalee District (1921-2012)

\begin{tabular}{lllllllllr}
\hline Census & \multicolumn{2}{l}{ Tamils (a) } & \multicolumn{2}{l}{ Muslims (b) } & \multicolumn{2}{l}{ Sinhalese } & \multicolumn{2}{l}{ Others } & Total \\
Year & No & $\mathbf{\%}$ & No & $\mathbf{\%}$ & No & \% & No & \% & \\
\hline 1921 & 18,580 & 54.47 & 12,846 & 37.66 & 1,501 & 4.40 & 1,185 & 3.47 & 34,112 \\
1946 & 33,795 & 44.51 & 23,219 & 30.58 & 11,606 & 15.29 & 7,306 & 9.62 & 75,926 \\
1953 & 37,517 & 44.71 & 28,616 & 34.10 & 15,296 & 18.28 & 2,488 & 2.96 & 83,917 \\
1963 & 54,452 & 39.30 & 40,775 & 29.43 & 39,925 & 28.82 & 3,401 & 2.45 & 138,553 \\
1971 & 71,749 & 38.11 & 59,924 & 31.83 & 54,744 & 29.08 & 1,828 & 0.97 & 188,245 \\
1981 & 93,132 & 36.39 & 75,039 & 29.32 & 85,503 & 33.41 & 2,274 & 0.89 & 255,948 \\
2012 & 122,080 & 32.20 & 152,854 & 40.27 & 101,991 & 26.97 & 1,257 & 0.33 & 378,182 \\
\hline
\end{tabular}

(a) Sri Lanka Tamils and Indian Tamils (b) Sri Lankan Moors and Malays

Source: Department of Census and Statistics $2007 \& 2012$.

\subsection{Gal Oya and Other Irrigation-Based Land Settlement Projects and Their Impact in the Amparai District}

One of the districts in the eastern province severely affected by the land settlement and colonization projects is Amparai. Before the district was formed in 1961, the Muslims and the Tamils had been living with a long history of predominance in this region. However, the successive land settlement and colonization projects based on the Gal Oya and Mahaweli irrigation-based projects, not only allowed thousands of acres of lands owned by Muslims and by Tamils to be seized by government authorities in order to settle more Sinhalese, but also led to the progressive increase of Sinhalese among the district's population.

The Gal Oya irrigation-based development project was a major project initiated by the post-independent government in Sri Lanka. This project was initiated in 1949 by the then UNP government under the leadership of D.S Senanayaka, the first Prime Minister of Sri Lanka, when the present day Amparai district was a part of the Batticaloa district. Through the project, an area of more than 120,000 acres of irrigable land was developed and allotted to settlers between 1949 and 1952 (Peebles, 1990:37). According to Hasbullah et al. (2005:35-37), under this colonization scheme, allotters were selected overwhelmingly from the Sinhalese rather than from the Muslims and the Tamils who formed a majority in the region at that time; the consequences of this has lopsided the ethnic balance of the Amparai district.

When the Gal Oya scheme was inaugurated, D.S. Senanayake promised that the new lands that were cultivatable under the scheme would be distributed on a 50:50 basis between the local citizens and the colonists selected from the outside (Ibrahim 2001; Mohideen 2013). Since Muslims constituted about 70\% of the region's population at that time, Muslim politicians welcomed the project and worked for the success of the project. However, contrary to the promises made, Muslims and Tamils were only settled in six villages out of the 44 new 
settlement villages formed under this project. Studies reveal that furthermore, these six villages have suffered a lot due to the shortage of water during the dry season, which compelled some settlers to leave the settlement later (Mohideen, 2013:82; Hasbullah et al., 2005: 33-37). As Mohideen (2008) criticizes, the opening of the Gal Oya scheme was a great boon to the Sinhala people, but Muslims viewed it as a device to deprive them of living and owning lands in the district. This was the stance of the Tamils too. According to the minorities' version of this history, the colonists settled under this project were selected overwhelmingly among the Sinhalese rather than from the Muslims and Tamils, who were the majority in the region at that time. As a result, both the Muslims and the Tamils were faced with severe land shortage in the Amparai district, while the ethnic balance of the district was also disrupted. Table-2 illustrates the changing dynamics of the population in the Amparai district within a fifty years period. Furthermore, through this process, land was also allocated favoring the Sinhalese through limiting the boundaries of local political and administrative units, thereby violating the rightful share of ethnic minorities. Table-3 clearly reveals this fact.

Table 2. The changing ethnic balance in the population of Amparai district (1963-2012)

\begin{tabular}{lccccccccc}
\hline Census & \multicolumn{2}{c}{ SL Muslims } & \multicolumn{2}{c}{ Sinhalese } & \multicolumn{2}{c}{ SL Tamils } & \multicolumn{2}{c}{ Others } & Total no. \\
Year & \multicolumn{1}{c}{ No } & $\mathbf{\%}$ & \multicolumn{1}{c}{ No } & $\mathbf{\%}$ & No & $\mathbf{\%}$ & No & \% & \\
\hline 1963 & 97,621 & 46.11 & 61,996 & 29.28 & 49,185 & 23.23 & 2,930 & 1.38 & 211,732 \\
1973 & 126,365 & 46.35 & 82,280 & 30.18 & 23,456 & 8.40 & 3,441 & 1.26 & 272,605 \\
1981 & 161,568 & 41.45 & 146,943 & 37.78 & 77,826 & 20.20 & 2.633 & 0.67 & 388,970 \\
2012 & 282,484 & 43.59 & 251,018 & 38.73 & 112,750 & 17.40 & 1,805 & 0.28 & 648,057 \\
\hline
\end{tabular}

Source: Department of Census and Statistics 2007; 2012 \& 2014.

It is worth noting here that Muslims comprise about $43.6 \%$ of the Amparai district's population, but only about $17.2 \%$ of the total district's land has been allocated to the Muslim-majority DS divisions in the district. Similarly, the Tamils make up $17.4 \%$ of the district's population, but only $9.2 \%$ of the district's land is allocated to the Tamil-majority DS divisions in the district. On the other hand, about three quarters of the lands in the district belong to the DS divisions that almost entirely consist of Sinhalese populations, i.e., about $73.6 \%$ of the total district's land is allocated to the Sinhalese-majority DS divisions, even though the Sinhalese constitute only $38.7 \%$ of the district's population.

Table 3. Land distribution based on ethnic group-dominated DS divisions in the Amparai district (2012)

\begin{tabular}{|c|c|c|c|c|}
\hline \multirow{2}{*}{$\begin{array}{l}\text { DS divisions } \\
\text { predominated by } \\
\text { ethnic groups }\end{array}$} & \multicolumn{2}{|c|}{$\begin{array}{l}\text { Share in district population } \\
\qquad(2012)\end{array}$} & \multicolumn{2}{|c|}{$\begin{array}{l}\text { Allocated land for DS divisions } \\
\text { predominated by ethnic groups }\end{array}$} \\
\hline & Amount & $\%$ & Amount (KM $\left.{ }^{2}\right)$ & $\%$ \\
\hline Muslims & 281,702 & 43.6 & $7,59.4$ & 17.2 \\
\hline Sinhalese & 252,458 & 38.7 & $3,248.5$ & 73.6 \\
\hline Tamils & 112,457 & 17.4 & 407.1 & 9.2 \\
\hline Others & 2,785 & 0.3 & - & - \\
\hline Total & 649,402 & 100 & 4,415 & 100 \\
\hline
\end{tabular}

Source: District Secretariat, Amparai 2013.

The Gal Oya project has also involved the creation of state-owned plantations in the region in order to cultivate new cash crops, particularly sugar cane. Sinhalese settlers were the primary beneficiaries of the sugar cane production, which was sold at a state-guaranteed price. At the same time, the sugar cane cultivation reduced water supplies for less lucrative paddy production by the Tamil and the Muslim farmers (Thangarajah, 2003:25). As IGC (2008:5) reports, due to the layout of existing settlements and land use, the bulk of Sinhalese farmers over the years were able to settle down in the western part of existing Tamil and Muslim communities' living areas and thus became closer to water sources. These Sinhalese have generally received more and more 
consistent water facilities, and this has become a frequent complaint amongst the Tamil and Muslim farmers of the district. Later, the Tamils and the Muslims were allowed to develop their livelihood activities in their traditionally owned lands, however, they were compelled to limit their settlements in the coastal belt. This created a number of land-based issues for the Tamil-speakers living in the coastal belt of the Amparai district. To quote a recent example, the land shortage faced by the Muslims resulted in them challenging the process of resettlements and development, especially after the 2004 Asian tsunami devastation that killed about 11,000 people - mostly Muslims and Tamils - and destroyed almost all the basic amenities in the coastal belt of the Amparai district.

\section{Mahaweli Project and Its Impact on Ethnic Minorities in Eastern Sri Lanka}

Another major irrigation-based land settlement program that has caused ethnic tension and intensified the ethnic conflict in Sri Lanka was the Accelerated Mahaweli development program - the biggest river basin development program conceived in Sri Lanka - implemented by the United National Party (UNP) government from 1978 onwards. Soon after the sweeping victory of the 1977 general election under the leadership of J.R. Jeyawardena, the UNP government introduced a program of economic liberalism and a series of development projects, including the Accelerated Mahaweli Program, to relieve economic pressure (Peebles, 1990:41). The objectives of the Mahaweli Development Scheme were related to regulating and harnessing the waters of the Mahaweli river for land settlement, power generation, agricultural activities, and food production and thereby the provision of employment (Mahaweli Authority, 2014). As late as May 1982, Mahaweli project officials claimed that reduced unemployment in dry zone settlements would eradicate ethnic tension. However, as Peeble (1990:41) notes, they were unduly optimistic, as earlier colonization schemes had divided the Sinhalese majority and the Tamil minority long before the Mahaweli project was designed.

The Mahaweli development project was initially proposed in 1968 under the United National Front (UNF) government as a thirty-year project. However, the new UNP government that came to power in 1977 reported that it would implement the entire thirty-year development plan in six years under the theme of 'Accelerated Mahaweli Project.' This claim was motivated by the over-whelming public support received in the 1977 general election, continuous propaganda barrages, and the government's success in attracting massive foreign aid. It is worth noting here that even though the project was propagated as having a development motive - to facilitate more job opportunities with substantial economic development - the project ultimately aimed at disturbing ethnic relations between the Tamils and the Sinhalese through especially focusing on projects and programs for the Sinhalese. Eventually, under this project, four major dams were built and an estimated 390,000 acres of new land were settled by 140,000 families, most of them in the eastern province in the Mahaweli and adjacent Maduru Oya (river) basins (Peebles, 1990:43). A noteworthy fact is that from the era of independence onwards, no major irrigation-based project has been implemented in the Tamil-speakers predominated areas in the north-eastern region that has benefited them. For example, successive governments, especially the Jeyawardene government accelerated the Mahaweli project with the intention of appealing to its Sinhalese constituencies. Furthermore, beyond providing direct economic benefits to Sinhalese constituencies, the Jeyawardene government linked the accelerated Mahaweli program to the restoration of the ancient Sinhalese civilization (For more detail see: Jeyawardene, 1982). In addition to sponsoring irrigation projects under the Mahaweli project, the government also encouraged private groups to focus on developing more Sinhalese settlements in many parts of the north-eastern region during the period of the Mahaweli project.

One important aspect of the accelerated Mahaweli project with regard to minorities was the expansion of an irrigation project to the Eastern province [called Zone L \& M], which has severely impacted the Tamils' discourse of a 'traditional homeland' in the north-eastern region. In the initial Mahaweli project, there was no plan to direct the Mahaweli river to the eastern province. However, the UNP government turned it towards the eastern province. It should also be noted that the expansion of the Mahaweli irrigation project into the Manal Aru (Weli Oya) region in the northern reaches of the Trincomalee district in the eastern province in the 1980s was particularly controversial. While it was designated as the 'Mahaweli-L scheme' that came under the jurisdiction of the Mahaweli Authority, the areas were always too remote to receive actual water from the Mahaweli river. Instead, as Fonseka \& Jegatheeswaran (2013:55) argue, the administrative powers of the Mahaweli authority were used to legitimize a largely military-led project to settle a Sinhalese community that could act as a buffer to the expansion of LTTE control in this area. Settling Sinhalese at the border of the eastern and the northern provinces was also designed to undermine Tamil nationalists' claim of 'a contiguous north-eastern Tamil homeland.' The Tamil nationalists have maintained that this was an attempt at bifurcating the north from the east with a string of Sinhalese settlements. In order to further undermine the Tamils' 'homeland' demand and to legitimize the Sinhalese settlements in these areas, the central government has declared these areas as a separate 
Divisional Secretariat (DS) division empowered with substantial fund allocations.

As Peebles (1990:32) rightly mentions, the colonization of the dry zone has intensified Sri Lanka's ethnic conflict because it evoked Sinhalese ethnic myths that idealized the prosperity and simple piety of the ancient Sinhalese while exaggerating the hostility of the Tamils, whom the Sinhalese believed threatened the very existence of Buddhism and who eventually drove the Sinhalese from the dry zone. Tamils, on the other hand, by claiming a territory called the 'Tamil homeland' in the north-eastern part on the basis of their own ethnic myths, have heightened the Sinhalese fear and made it impossible for the government to deal with the issue rationally, thus leading to the Tamils choosing a violent way of achieving their homeland. Consequently, the colonization project has become a nonnegotiable subject for people on both sides and has intensified Sri Lanka's violence and civil war over the course of time.

As the Sinhalese settled and established armed villages, thousands of Tamil families were forcibly displaced by the army from their traditional villages in these areas due to the civil war. Among those forced out were hundreds of Tamils of Indian origin who had settled down and worked on Tamil-owned farms in these areas after fleeing the 1977 organized riots in the south and central highlands of the country. The process of militarized settlement in the Weli Oya region was halted by the war, but now appears to have been revived in order to repopulate and expand the previously established Sinhalese areas. From the perception of the minorities, the movement of Sinhalese settlers into these areas is part of the central government policy of Sinhalization in the region, and not the result of entrepreneurial activities of local commanders and businessmen (Manimaran, 2013).

After the end of civil war in May 2009, the central government with the assistance of military authorities attempted to settle the displaced families with more new Sinhalese settlers in this region. Politicians promised the returners who were displaced due to the civil war that additional lands would be made available in the north as the reservoirs and lands were abandoned by the Tamils during the war. The decision to transfer formal administrative control over the Weli Oya area to the Mahaweli authorities meant that Tamil district and divisional level officials would lose the control they had over the land in those areas where Tamils remained the majority. Furthermore, as ICG (2012) identified, there are also plans to regularize the questionable status of land titles and permits held by many of the Sinhalese settlers from the 1980s and 1990s, and legalize their semi-legal settlements. Many Tamils criticize not only these Sinhalese settlements but also the government's October 2011 decision to shift the Weli Oya division from the Sinhala majority district of Anuradhapura to Mullaitivu, making it the first Sinhala-majority division in a virtually all Tamil district (Note 2).

Table 4. Population change of eastern province - ethnic group basis (1921-2012)

\begin{tabular}{lccccccccr}
\hline Census & \multicolumn{2}{c}{ Tamils (a) } & \multicolumn{2}{c}{ Muslims (b) } & \multicolumn{2}{c}{ Sinhalese } & \multicolumn{2}{c}{ Others } & \multirow{2}{*}{ Total no. } \\
Year & No & \% & \multicolumn{1}{c}{ No } & \multicolumn{1}{c}{$\%$} & \multicolumn{1}{c}{ No } & \multicolumn{1}{c}{$\%$} & \multicolumn{1}{c}{ No } & \multicolumn{1}{c}{$\%$} & \\
\hline 1921 & 103,245 & 53.54 & 75,992 & 39.41 & 8,744 & 4.53 & 4,840 & 2.51 & $\mathbf{1 9 2 , 8 2 1}$ \\
1946 & 136,059 & 48.75 & 109,024 & 39.06 & 23,456 & 8.40 & 10,573 & 3.79 & $\mathbf{2 7 9 , 1 1 2}$ \\
1953 & 167,898 & 47.37 & 135,322 & 38.18 & 46,470 & 13.11 & 4,720 & 1.33 & $\mathbf{3 5 4 , 4 1 0}$ \\
1963 & 246,059 & 45.03 & 184,434 & 33.75 & 108,636 & 19.88 & 7,345 & 1.34 & $\mathbf{5 4 6 , 4 7 4}$ \\
1971 & 315,566 & 43.98 & 247,178 & 34.45 & 148,572 & 20.70 & 6,255 & 0.87 & $\mathbf{7 1 7 , 5 7 1}$ \\
1981 & 410,156 & 42.06 & 315,436 & 32.34 & 243,701 & 24.99 & 5,988 & 0.61 & $\mathbf{9 7 5 , 2 5 1}$ \\
2012 & 617,295 & 39.79 & 569,738 & 36.72 & 359,136 & 23.15 & 5,212 & 0.34 & $\mathbf{1 , 5 5 1 , 3 8 1}$ \\
\hline
\end{tabular}

(a) Sri Lankan Tamils and Indian Tamils (b) Sri Lankan Moors and Malays

Source: Department of Census and Statistics 2007 \& 2012.

Ultimately, Tamil-speaking communities, who formed the majority in the eastern province population, viewed these government-sponsored projects as state-driven colonization projects that favored the Sinhalese from outside the province and dramatically impacted the demography of the region. An analysis of the population change in terms of ethnic groups of the province justifies this argument to a greater extent. For example, since independence, the Sinhala population in the eastern province has sharply increased from $8.4 \%$ in 1946 to $24.9 \%$ in 1981. There were only 23,456 Sinhalese in the eastern province in 1946, but in 1963 the region had a Sinhalese population of 108,636 , and in 1981 , this figure increased to 234,701 . These statistics justify the claim 
that the Sinhalese population of the eastern province has rapidly increased in merely thirty-five years, as a result of the above-mentioned land-based settlement projects implemented in the province. Conversely, the percentages of Tamil-speaking minorities have decreased in the region. Table- 4 elaborates on the changes in ethnic composition in the eastern province.

Whatever the prevailing reality, there are contesting arguments and different viewpoints with regards to the land settlement and land- (and irrigation) based development programs initiated and implemented in the Tamil-speakers predominated eastern province. Minority Tamils and Muslims feel that the government has favored empowering the Sinhalese community and has attempted to increase the Sinhalese population in the region through these projects. According to them, land development/settlement and massive irrigation projects are designed to improve the economic conditions of the Sinhalese, and steps have not been taken by Sinhalese dominated governments to improve the economic and social conditions of the Tamils and the Muslims living in the region. Furthermore, these concentrated settlements of Sinhalese in the eastern province have resulted in more political leverage for Sinhalese living in some districts (See: Manogaran, 1987:95-97).

There is an abiding concern among Tamil-speaking minorities that the government is continuing its attempts to provide more lands for the Sinhalese and is attempting to decrease the Tamil-speaking population in the region, even in the post-war context. Many initiatives taken by the central government in the districts of the eastern province provide evidence in support of these worries. Many Sinhalese villages, especially newly established settlements, have been upgraded to the status of separate Divisional Secretariat (DS) (the major administrative unit under district), by merging some villages of Tamil-speaking communities. There were occasions where many Sinhalese majority villages were merged with Tamil and Muslim majority DS divisions, which had tremendous impact on ethnic composition within the division and the district, as well as affecting electoral politics. Furthermore, there was an attempt a few years ago to establish a new district by carving out a DS division from the Mullaitivu, Anuradapura, and Trincomalee districts, which was intended to act as a buffer between the northern and the eastern provinces. Fonseka \& Raheem (2010:54) viewed this as a possible attempt to break the territorial contiguity of the concept of the 'Tamil Homeland.' Additionally, the Tamils have viewed these policies as an attempt to change the ethnic composition of the areas where they traditionally have predominated. As discussed earlier, these colonization projects have made substantial changes in population distribution and raise some issues of general interest in the area of ethnic conflict. Table-1, Table-2, and Table-3 clearly justify this argument.

However, for the Sinhala community, the granting of land to Sinhalese is seen as a positive process aimed at distributing land to the landless. There is also a perception among the Sinhalese that they are not 'stealing' land from the minorities but are actually and merely re-claiming land that they abandoned centuries ago, especially given the historical sites and references in the north-east historic narratives (Fonseka \& Raheem, 2010:26). Furthermore, some claim that the process of land settlements in the north-eastern region is to establish inter-racial equity (See: Marga, 1985). Sinhala nationalists further point out that individual and politician-sponsored settlement projects for Tamils and Muslims are evidence of colonization by minorities.

There are some points to be noted with regards to the seizure of Tamil-speakers' lands and the settlement of more Sinhalese in the eastern region. Land settlement schemes in the name of protecting the peasantry and increasing paddy/food production were not just another development activity. Rather, the schemes encompassed a whole range of objectives. They were a means of redressing past grievances and correcting colonial injustice. As these schemes were expected to improve and protect the life of the vast majority of the population, they were a principal foundation of the post-colonial state. Furthermore, these land policies in turn were essential for the consolidation of the centralized state. The policies consolidated the relationship between the ruling class that controlled the centralized state and the rural Sinhalese who formed the majority. Land policies, reforms, and land settlement projects were focused on this objective.

It is also worth noting here that the land policies and land settlement projects have induced the emergence of territorial-based political claims (territorial autonomy, self-rule and separate state) in Sri Lankan ethnic conflict. Every land settlement in the dry zone of the eastern province has been a major source of grievance among Tamil-speaking minorities, contributing to the demands of territorial autonomy among the Muslims, and a separate state among the Tamils. A systemic review of the minorities' demands in the discourse of this ethnic conflict reveals that stopping land seizures and land settlements in the eastern region, and granting more autonomy in land affairs to the northern and eastern provincial councils were the major two claims of minorities (See: Hasbullah et al., 2005; Uyangoda, 2009; Fonseka \& Raheem, 2010; Sarjoon, 2011; Fonseka \& Jegatheeswaran, 2013). Furthermore, land settlements and development projects were one of the main causes of the civil war. As Korf \& Tudor Silva (2003:2) indicate, even though there have been numerous fallouts of the 
war elsewhere in Sri Lanka, the dry zone has been the main theatre of war in Sri Lanka for the past two decades. The geographical basis of the armed conflict in the north-eastern region of the island is typically understood in terms of ethnic-wise population distribution in the country. Various parts of the northern and the eastern provinces are being tenuously held by Sri Lankan armed forces and the LTTE, with the former determined to preserve the territorial integrity of the Sri Lanka nation and the latter fighting for an independent Tamil homeland (Eelam) merging the two provinces. State-owned and state-controlled colonization programs, in particular, have been heavily criticized and often targeted by the Tamil fighters, accusing these programs as an effort to expand the Sinhala frontier into the so called 'Tamil homeland.' In fact, the separate state (homeland) demand, to a considerable extent, has challenged the ability of the central state to control land in the northern and the eastern provinces.

Even though the thirteenth amendment to the constitution made in 1987, intended to resolve ethnic conflict by devolving powers to provincial councils and granting land related powers to these councils, successive central governments controlled by the Sinhalese have shown little interest in fully granting of such powers to be exercised by the councils in these provinces. The present context of issues related to decentralization and power-sharing in Sri Lanka has created a situation where the resolution of ethnic conflict cannot be achieved without reframing the centralized state and establishing territorial based autonomous units which are empowered to control the lands within their territories, in order to accommodate ethnic and regional minorities living in north-eastern Sri Lanka.

\section{Conclusion}

As examined above, the land policies and land settlement projects implemented by successive post-independence Sri Lankan governments motivated by the need for development in the undeveloped interior regions of the island, have contributed a number of benefits in particular to the Sinhalese, with a negative impact on the rights of minorities, engendering the development of territory-based political claims, ethnic conflict, and violent civil war in Sri Lanka. These policies and projects provided more lands to the landless Sinhalese peasantry and improved their livelihood in the predominantly Tamil-speaking eastern region while strengthening their presence in the region. Furthermore, these policies and projects have facilitated the Sinhalese politically and administratively. On the other hand, these initiatives have alienated the minorities and have made objective changes to population distribution in the region as well as in the whole country. All these calculated attempts and their impact have resulted in the emergence of claims and advocacy for more decentralized powers, territorial autonomy, and a separate state along with the breakdown of majority-minority ethnic relations and mutual interethnic understanding, and the eventual increase of violence and civil war in the region. As discussed earlier, land policies and land settlement programs have negatively influenced the lives and livelihoods of minorities in the eastern region, and also contributed towards the violation of their rights, which in turn has become a source of ethnic conflict and civil war in the country. Therefore, as a developing country that has experienced the severe negative impact of land policies and land settlement programs, Sri Lanka needs to resolve the land issues faced by its ethnic minorities in the eastern province as a condition to build lasting peace and sustainable development in the post-war environment.

\section{References}

Department of Census and Statistics. (2007). Special enumeration-Eastern province 2007. Colombo: Department of Census and Statistics.

Department of Census and Statistics. (2012). Census of population and housing-2012. Colombo: Department of Census and Statistics.

Department of Census and Statistics. (2014). Census of population and housing-2012 (New)- Final report. Colombo: Department of Census and Statistics. Retrieved March 3, 2015, from http://www.statistics.gov.lk/PopHouSat/CPH2012Visualization/htdocs/index.php?usecase=indicator\&action $=$ Map\&indId $=10$

District Secretariat, Amparai. (2013). Annual performance report and budget 2012. Amparai: District Secretariat.

Fonseka, B., \& Jegatheeswara, D. (2013). Politics, policies and land acquisition and related issues in the north and the east of Sri Lanka. Colombo: Center for Policy Alternative.

Fonseka, B., \& Raheem, M. (2010). Land in the eastern province: politics, policy and conflict. Colombo: Center for Policy Alternative.

Hasbullah, S. H., Balasundarampillai, P., \& Tudor Silva, K. (2005). Addressing root causes of the conflict: land problems in the north-east Sri Lanka. Colombo: Foundation for Co-Existence. 
Ibrahim, I. L. M. (2001). Kalmunai coastal district. Sammanthurai: Author's Publication.

International Crisis Group (ICG). (2008). Sri Lanka's eastern province: land, development, conflict. London: ICG.

International Crisis Group (ICG). (2012). Sri Lanka's north I: the denial of minority rights. London: ICG.

Jeyawardena, S. (1982). History of Maduru Oya. Dehiwala. Colombo: Sri Lanka: Cultural Publications Co.

Jinapala, K., Somarathne, P. G., Ariyaratne, B. R., \& Merrey, D. J. (2012). Improving the sustainability of impacts of agricultural water management interventions in changing context. The case study for Sri Lanka. Colombo: International Water Management Institute.

Karunanayake, M. M., \& Abhayaratne, M. D. C. (2002). Redefining regional development in Sri Lanka: realities and challenges. CMU. Journal, 1(3), 303-319.

Korf, B., \& Tudor Silva, K. (2003). Poverty, ethnicity, and conflict in Sri Lanka. Retrieved November 6, 2014, from http://www.chronicpoverty.org/uploads/publication_files/CP_2003_KorfSilva.pdf

Mahaweli Authority. (2014). Master plan. Colombo: Mahaweli Authority. Retrieved November 25, 2014, from http://mahaweli.gov.lk/en/mp.html

Manimaran, S. Civil activists, Interviewed on 18.08.2013. Jaffna.

Manogaran, C. (1987). Ethnic conflict and reconciliation in Sri Lanka. Honolulu: University of Hawaii Press.

Marga. (1985). Inter-racial equity and national unity in Sri Lanka. Colombo: Marga Institute.

Mohideen, M. I. M. (2008). Sinhalisation of East: a reply to Minister Champika Ranawaka. Retrieved December 18, 2014, from http://www.island.lk/2007/12/27/features5.html

Mohideen, M. I. M. (2013). Eastern Muslims must unite politically. Colombo: Al-Ceylan Muslim Documentation Center.

Peebles, P. (1990). Colonization and ethnic conflict in the dry zone of Sri Lanka. The Journal of Asian Studies, 49(1), 30-55. http://dx.doi.org/10.2307/2058432

Rupasinghe, K. (2002). Enhancing human security in the Eastern province. Colombo: Center for Policy Alternative.

Sarjoon, A. (2011). Changing dynamics of minority rights discourse in Sri Lanka's eastern province: a study of the Muslim demand for autonomy. (Unpublished Master Thesis). University of Colombo. Colombo, Sri Lanka.

Thangarajah, Y. (2003). Ethnicization of the devolution debate and the militarization of civil society in Sri Lanka. In M. Mayer, D. Rajasingham-Senanayake, \& Y. Tangarajah (Eds.), Building local capacities for peace: rethinking conflict and development in Sri Lanka (pp.15-36). New Delhi: Macmillan India.

University Teachers for Human Rights (Jaffna) Sri Lanka (UTHR(J). (1993). Colonization and demographic changes in the Trincomalee district and its effects on Tamil speaking people (Report 11). Jaffna: UTHR(J). Retrieved May 11, 2015, from http://www.uthr.org/Reports/Report11/appendix2.htm

Uyangoda, J. (2009). Sri Lanka: recent shift in the minority rights debate. In R. Manchanda (Ed.), Living on the margins: minorities in South Asia (pp. 99-120). Katmandu: EUROASIA-NET Partners.

Yusoff, M. A., Sarjoon, A. Asrinaldi, \& Mohd Zain, Z. (2015). Decentralized administration and minority accommodation in Sri Lanka: analyzing the status, issues, challenges and prospects. Mediterranean Journal of Social Sciences, 6(4S1), 533-542. http://dx.doi.org/10.5901/mjss.2015.v6n4s1p533

\section{Notes}

Note 1. The AGA division was the local level administration division under the district. A district was divided into many AGA divisions. This level of administrative unit was formed in the 1950s and functioned until 1990. The AGA divisions were transformed into Divisional Secretariat (DS) division in 1990 empowered with more de-concentrated powers through Transfer of Powers (Divisional Secretaries') Act, No- 58 of 1992. For more information see: Jinapala etal (2012) \& Yusoff etal (2015).

Note 2. Initially, the territory of Weli Oya District Secretariat was as part of Trincomalee district under the control of district secretary. In the cause of civil war, it was attached with the Anurathapura district. However, at the end of civil war, the division is attached with the district of Mullaitivu as the one and only Sinhalese majority 
district. For further details on this regard, see, ICG (2008); Fonseka \& Raheem (2010); IGC (2012); Fonseka \& Jegatheeswara (2013).

\section{Copyrights}

Copyright for this article is retained by the author(s), with first publication rights granted to the journal.

This is an open-access article distributed under the terms and conditions of the Creative Commons Attribution license (http://creativecommons.org/licenses/by/3.0/). 